Universal Decimal Classification (UDC) number 613.64: 616.717 - 057

\title{
ASSESSING THE RISK OF DEVELOPING THE METABOLIC SYNDROME AS A PREDICTOR OF CARDIOVASCULAR PATHOLOGIES IN OIL-EXTRACTING COMPANY WORKERS
}

\author{
A.S. Baydina, V.B. Alexeyev, A.Ye. Nosov, Ye.A. Shirinkina
}

FBSI «Federal Scientific Center for Medical and Preventive Health Risk Management Technologies», Russian Federation, Perm, 82 Monastyrskaya St., 614045

\begin{abstract}
The results of assessing the risk of the metabolic syndrome development in oil-extracting company workers has shown that occupational exposure to aromatic hydrocarbons should be considered as a risk factor for cardiovascular disease. It was found that among the workers exposed to aromatic hydrocarbons the prevalence of metabolic syndrome is increased by $16 \%$ and hypertension by $13.9 \%$. In occupational groups exposed to aromatic hydrocarbons, the individual components of the metabolic syndrome such as hyperuricemia (EF 52,33\%) and hyperleptinemia (EF 33,02\%) and the metabolic syndrome in general (EF 36,75\%) are occupation-related. Etiological contribution of benzene and toluene in the development of the metabolic syndrome is $4.62 \%$.

Key words: aromatic hydrocarbons, metabolic syndrome, oil-extracting company, hypertension, hyperuricemia, hyperleptinemia.
\end{abstract}

Circulatory system disorders constitute the leading cause of death. The main human losses including persons of working age, are due to diseases associated with atherosclerosis: coronary heart disease (CHD), cerebrovascular disease (CVD), arterial hypertension (AH), atherosclerotic lesions of the aorta and peripheral arteries.

The proportion of cardiovascular disorders among the causes of temporary disability is $12 \%$ and of the permanent disability - nearly $50 \%$ [2]. Working population affected by the double load of industrial and non-occupational factors, is considered as a risk group. [8]

Oil industry enterprises are of a strategic importance for the economy of the Russian Federation. At the territory of Russia over $18 \%$ of the world production of hydrocarbons is extracted [4]. The oil-extracting industry is of the key importance for the economy of the Perm region. According to the data of territorial authority of the Federal State Statistics Service, the average annual number of workers employed in the production of fossil fuels constitutes 14.7 thousand people. Half of the total number of employees work under hazardous conditions. Among the workers of the oil-extracting industry the prevalence of arterial hypertension is

(C) Baydina, A.S.,Alexeyev, V.B., Nosov, A.Ye., Shirinkina, Ye.A.,2013

Baydina Anastasia Sergeyevna - Cardiologist, the Outpatient Department (e-mail: x_ray@perm.ru, tel.: +7 (342) 236-87-60).

Alexeyev VadimBorisovich - DSc in Medicine, Deputy Director for Organizational and Methodical Work (e-mail: vadim@fcrisk.ru, tel.: +7 (342) 237-25-34).

Nosov Alexandr Yevgenyevich - PhD in Medicine, Head of the Adult Outpatient Depertment, the Centre for Occupational Medicine and Pathology (e-mail: nosov@fcrisk.ru, tel.: +7 (342) 237-87-80).

Shirinkina Yelena Anatolyevna - Endocrinologist, the Outpatient Department (e-mail: root@fcrisk.ru, tel.: +7 (342) 236-87-60). 
43.2\%, hypercholesterolemia - $48.3 \%$ and obesity $-10.4 \%$ [9].

Due to the high rate of mortality caused by cardiovascular disease (CVD) and polyetiologic nature of this pathology, the assessment of contribution of occupational factors in the formation of the risk of these disorders is relevant. Among the potential risk factors in the context of negative effects on the cardiovascular system of oil-extracting workers (noise, vibration, hardness of the labour process, microclimate, light conditions), are also various chemical substances present in the air at the workplace. [1] The main and constant chemical occupational risk factor is the complex of various hydrocarbons. Different types of crude oil contain from 10 to $20 \%$ of aromatic hydrocarbons. [8] Traditionally, greater attention is paid to the effect of physical and psycho-physiological factors on the cardiovascular system of workers, while the studies on the influence of chemical factors are limited. Literature data on the effect of aromatic hydrocarbons on the cardiovascular system are scarce [3, 5-7, 10, 11].

The aim of the study was to allocate the risk factors of metabolic syndrome and to determine the contribution of aromatic hydrocarbons in the occupational environment to the development of the metabolic syndrome as a predictor of cardiovascular disease in workers of the oil-extracting enterprise.

Materials and methods. The object of the study included 242 oil-extracting company workers (oil and gas production unit), which are subject to the occupational exposure to aromatic hydrocarbons, as well as their working conditions and lifestyle.

The monitoring group comprised 192 persons, which according to the cards of workplace labour conditions compliance certification were subject to chemical exposure factors. The comparison group consisted of 50 company workers, who according to the cards of workplace labour conditions compliance certification had no likely exposure to chemical factors. The monitoring group included oil and gas extraction operators, and in the comparison group operators of dewatering and desalting unit, operators of pumping stations for pumping of the working fluid into the reservoir. The mean age of workers in the monitoring group was $38.2 \pm$ 10.5 years, in the comparison group $-37.3 \pm 10.8$ years, $\mathrm{p}=0.6$. The term of the work experience at the enterprise in the main group was $12.0 \pm 9.2$ years, and in the comparison group $-10.6 \pm 9.3$ years, $p=0.3$. The study included only men.

Evaluation of working conditions was carried out according to the Guidelines R2.2.200605 "Guidelines on health-related assessment of factors of working environment and labour process. Criteria and classification of the working conditions". Collection, analysis and summarizing the results of certification of workplace labour conditions compliance were carried out. The content of chemical compounds (benzene, toluene, ethylbenzene, xylenes) in the air of 
the working zone and in the blood of workers was assessed. Chemical- analytical investigations of the blood and air samples were performed via gas chromatography using a "Kristall-5000" gas chromatograph, with a capillary column HP-FFAP $50 \mathrm{~m}$ long, $0.32 \mathrm{~mm} \times 0.50 \mu \mathrm{m}$ diameter, with a flame ionization detector. Blood tests were performed in accordance with Methodological Guidelines MUK 4.1.765-99 "Gas-chromatographic method for quantitative determination of aromatic hydrocarbons (benzene, toluene, ethyl benzene, o-, m-, p- xylene) in biological media (blood)".

A specialized clinical and laboratory investigation of workers was conducted, as well as a survey on assessment of social and lifestyle factors, examination by a cardiologist with waist circumference and blood pressure measurements, laboratory tests (blood glucose, total cholesterol, triglycerides, low-density lipoprotein cholesterol (LDL-C), high-density lipoprotein cholesterol (HDL-C), leptin and uric acid levels).

Laboratory diagnosis was performed using automatic biochemical analyser - Konelab (Finland) (serial number 21923, Registration certificate FS No. 2006/2924, compliance certificates ROSS FI.ME20.HO 1902, GOST 50444-92, GOST 51350-99).

The data were processed using Statistika 6.0 program as well as specially developed software. Quantitative characteristics in parametric data distribution were described using arithmetic mean and standard deviation and were presented as $M \pm s$, in nonparametric data distribution - using medians and interquartile range (25th and 75th percentiles) and were presented as $M e(25,75)$. The normality of distribution of quantitative characteristics was assessed using Shapiro-Wilk test. Qualitative characteristics were described using absolute values and the corresponding event rate (in \%). For the analysis of quantitative data with normal distribution the Student's t-test was applied, in case of different from normal distribution - Mann-Whitney test. For comparison of qualitative characteristics in the groups, Pearson's chi-squared test and Fisher test were used. To identify the link between the characteristics studied, Spearman and Pearson correlation analyses were carried out. Statistical processing of the data on social factors assessment was carried out using the software package SPSS 16.0 for Windows. The adequacy of the model was verified by analysis of variance procedure, based on calculation of the determination coefficient $\left(R^{2}\right)$. Differences were considered significant by $p \leq 0.05$. The comparative assessment of probabilistic relationship between characteristics in the groups was assessed by the odds ratio $(O R)$ and relative risk $(R R)$ with the analysis of $95 \%$ confidence interval $(C I)$, etiologic proportion of responses due to exposure to the risk factor $(E F)$.

Results and discussion. The main occupational factors affecting workers, included noise, vibration, hardness and intensity of the labour process, room climate, light conditions and 
chemical substances present in the air of the working zone. Chemical factor of the working environment was represented by combination of different hydrocarbons (aromatic hydrocarbons

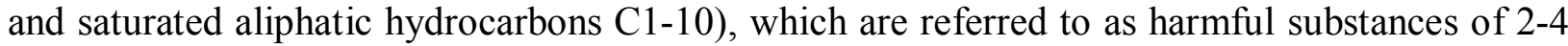
hazard grades.

Testing of air samples in the working zone for chemical substances content has shown that the samples taken contained different from zero concentrations of the studied organic compounds - benzene, toluene, ethylbenzene and xylene (Table 1). During the whole observation period the single-time concentrations sometimes exceeded the maximum level, but no exceeds in the average for the working shift permissible norms was observed in the air samples.

According to the results of certification of workplaces it was determined that the workers of groups of monitoring and comparison group have different classes of working conditions according to the chemical factor. In the monitoring group the general class of working conditions was certified as harmful working conditions (3.1), also according to the chemical factor (3.1). In the comparison group the general class of working conditions was certified as harmful working conditions (3.1), but according to the chemical factor it was certified as permissible (0-2.0).

In the result of chemical-analytical investigations it was found that benzene and toluene in significant concentrations were determined only in the blood of workers of the monitoring group (Table 2). The tested aromatic hydrocarbons (benzene, toluene, ethylbenzene, xylenes) in all blood samples were registered at concentrations significantly higher than background ones.

Exposure to other factors of the environment and the labour process was similar for both groups: at all workplaces equivalent levels of overall vibration comply with the Sanitary norms SN 2.2.4/2.1.8.566-96; parameters of the room climate conform to the permissible class of working conditions 2.0; hardness and intensity of the labour process at all workplaces correspond to class 2.0; occupational noise and light conditions - to class 3.1 (at all workplaces the registered noise levels exceeded the maximum permissible levels by $7 \mathrm{~dB}$ and the values of pulsation coefficient exceeded the norms by 16 to $34 \%$ ).

Table 1

Content of aromatic hydrocarbons in the air of the working zone in the oil-extracting plant (average concentration for a shift, $\mathrm{mg} / \mathrm{m}^{3}$ )

\begin{tabular}{|c|c|c|c|c|}
\hline Date & $\begin{array}{c}\text { Benzene, } \\
\text { maximal } \\
\text { permissible } \\
\text { concentration }=5\end{array}$ & $\begin{array}{c}\text { Toluene, } \\
\text { maximal } \\
\text { permissible } \\
\text { concentration }=50\end{array}$ & $\begin{array}{c}\text { Ethylbenzene, } \\
\text { maximal permissible } \\
\text { concentration = 50 }\end{array}$ & $\begin{array}{c}\text { Xylenes, } \\
\text { maximal } \\
\text { permissible } \\
\text { concentration }=50\end{array}$ \\
\hline \multicolumn{5}{|c|}{ Export pump platform Oil and gas production unit No. 12 } \\
\hline 05.07 .2011 & 0.0125 & 0.015 & 0.003 & 0.0043 \\
\hline \multicolumn{5}{|c|}{ Tank battery Oil and gas production unit No. 12} \\
\hline 05.07 .2011 & 0.0075 & 0.0078 & 0.001 & 0.0038 \\
\hline
\end{tabular}




\begin{tabular}{|c|c|c|c|c|}
\hline \multicolumn{5}{|c|}{ Oil-pumping Oil and gas production unit No. 11} \\
\hline 24.04.2012 & 0.005 & 0.008 & 0.003 & 0.01 \\
\hline \multicolumn{5}{|c|}{ Cluster pumping station 1109 Oil and gas production unit No. 11} \\
\hline 25.04 .2012 & 0.007 & 0.005 & 0.005 & 0.008 \\
\hline \multicolumn{5}{|c|}{ Borehole Oil and gas production unit No. 11} \\
\hline 24.04.2012 & 0.002 & 0.004 & 0.002 & 0.002 \\
\hline \multicolumn{5}{|c|}{ Booster pumping station 1101 Oil and gas production unit No. 11} \\
\hline 25.04 .2012 & 0.011 & 0.02 & 0.004 & 0.01 \\
\hline \multicolumn{5}{|c|}{ Oil-pumping Oil and gas production unit No. 5} \\
\hline 03.05 .2012 & 0.003 & 0.006 & 0.001 & 0.008 \\
\hline \multicolumn{5}{|c|}{ Cluster pumping station 1109 Oil and gas production unit No. 5} \\
\hline 03.05 .2012 & 0.003 & 0.006 & 0.002 & 0.011 \\
\hline \multicolumn{5}{|c|}{ Borehole Operator Oil and gas production unit No. 5} \\
\hline 04.05 .2012 & 0.002 & 0.004 & 0.001 & 0.004 \\
\hline \multicolumn{5}{|c|}{ Booster pumping station 1101 Oil and gas production unit No. 5} \\
\hline 03.05 .2012 & 0.005 & 0.008 & 0.001 & 0.013 \\
\hline
\end{tabular}

Table 2

Content of aromatic hydrocarbons in the blood $(\mu \mathrm{g} / \mathrm{cm} 3)$ in the monitoring group, in the comparison group and background concentrations

\begin{tabular}{|c|c|c|c|c|c|}
\hline Substance & $\begin{array}{c}\text { Monitoring group Me } \\
(25 ; 75)\end{array}$ & $\begin{array}{c}\text { Comparison group Me } \\
(25 ; 75)\end{array}$ & $\begin{array}{c}\text { Background } \\
\text { concentrations }\end{array}$ & $\mathrm{p} 1$ & $\mathrm{p} 2$ \\
\hline Benzene & $0.018(0.012 ; 0.03)$ & $0.00(0.00 ; 0.003)$ & 0 & $<0.001$ & $<0.001$ \\
\hline Toluene & $0.004(0.001 ; 0.011)$ & $0.00(0.00 ; 0.001)$ & 0 & $<0.001$ & $<0.001$ \\
\hline Ethylbenzene & $0.00(0.00 ; 0.003)$ & $0.00(0.00 ; 0.005)$ & 0 & $<0.001$ & 0.916 \\
\hline O-xylene & $0.00(0.00 ; 0.007)$ & $0.00(0.00 ; 0.004)$ & 0 & $<0.001$ & 0.855 \\
\hline p-, m-xylene & $0.00(0.00 ; 0.006)$ & $0.00(0.00 ; 0.003)$ & 0 & 0.003 & 0.948 \\
\hline
\end{tabular}

Note: $p_{1}$ - difference with background concentrations; $p_{2}$ - difference between the groups.

Medical and sociological assessment did not identify any significant differences between the monitoring and comparison groups in the prevalence of social risk factors (education level, income level, marital status), behavioural risk factors and negative lifestyle factors, $\mathrm{p}>0.05$.

In both groups high prevalence rates of abdominal obesity were observed: in the monitoring group $-49.4 \%$, in the control group - $46 \%, \mathrm{p}>0.05$.

In the group of workers exposed to aromatic hydrocarbons a higher prevalence of the metabolic syndrome and its individual components was found: 44\% - metabolic syndrome, $44.2 \%$ - arterial hypertension $20 \%$ - fasting hyperglycemia, dyslipidaemia manifested as decreased HDL-C and increased LDL-C, 42 \% - hyperuricemia; increased blood level of leptin which is a marker of the metabolic syndrome $(\mathrm{p} \leq 0.05)$.

The main cardiovascular disease observed in the workers exposed to aromatic hydrocarbons, is arterial hypertension. In the monitoring group arterial hypertension was registered in $44.2 \%$ of cases, and in the comparison group - in $30.3 \%, p=0.048$. Odds ratio 
analysis established a significant relationship between the development of arterial hypertension and increasing concentrations of benzene in the blood $\left(\mathrm{R}^{2}=0.433 ; \mathrm{p}<0.05\right)$ (see Figure).

Epidemiological analysis has shown (Table 3) that hyperuricemia and hyperleptinemia can be considered work-related, but to the high (EF - 52.33\%) and moderate (EF - 33.02\%) degrees of association of hyperuricemia and hyperleptinemia, respectively. In addition, also the metabolic syndrome as a whole can be regarded as work-related (EF - 36.75\%).

Health-related assessment of exposure of aromatics hydrocarbons on the working environment showed that benzene and toluene, even when present in the air of the working zone in concentrations not exceeding the average permissible levels for the working shift, contribute to the development of work-related metabolic syndrome in the oil-extracting plant workers - EF $1.72 \%$ and $2.9 \%$, respectively. It was determined that benzene and toluene reinforce the effect of traditional risk factors for metabolic syndrome in the workers of an oil-extracting plant.

Conclusions. The metabolic syndrome as a predictor of cardiovascular pathology in the workers exposed to aromatic hydrocarbons, is characterized by severe impairments of lipid, carbohydrate and purine metabolism and increased leptin levels in the blood. Such component of the metabolic syndrome as arterial hypertension is highly prevalent in this group. The prevalence of the metabolic syndrome and its components is higher in the professional groups exposed to aromatic hydrocarbons (the proportion of workers with metabolic syndrome is increased by $16 \%$, with fasting hyperglycaemia - by $12 \%$ and with arterial hypertension - by $13.9 \%$ ), in the absence of differences in social and behavioural risk factors. Epidemiological analysis demonstrated a high and moderate degree of correlation between the aromatic hydrocarbon content in the blood of workers and presence of metabolic syndrome $(\mathrm{OR}=2.04, \mathrm{EF}-36.75 \%)$, as well as its individual components (such as hyperleptinemia: $\mathrm{OR}=1.89, \mathrm{EF}-33.02 \%$ and hyperuricemia: $\mathrm{OR}=5.48, \mathrm{EF}-52.3 \%$ ). Etiological contribution of benzene and toluene in the development of metabolic syndrome is about $5 \%$.

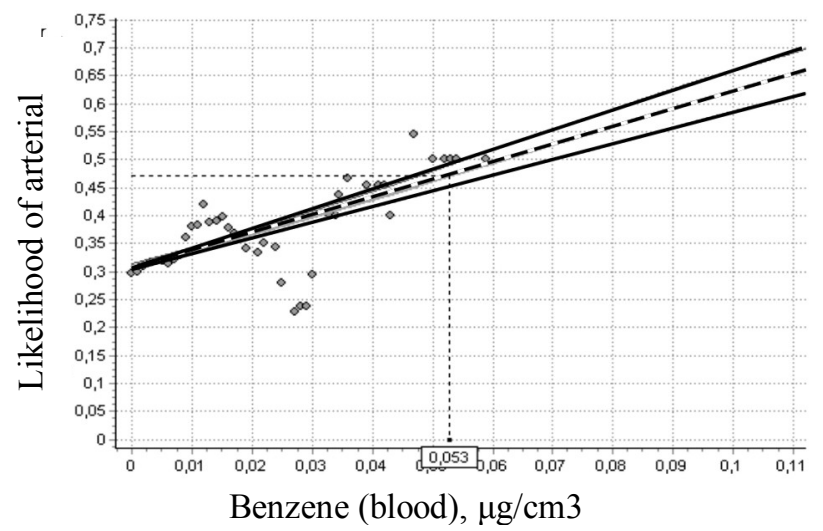

Figure. Relationship between the likelihood of arterial hypertension development and benzene content in the blood; $\mathrm{R} 2=0,433 ; \mathrm{p}<0.05$ 
Table 3

\section{Epidemiological indicators of the degree of the causal relationship between the metabolic syndrome and its components and aromatic hydrocarbon content in the blood of workers}

\begin{tabular}{|c|c|c|c|c|}
\hline Health disorders & $\begin{array}{c}\mathrm{OR} \\
(95 \% \mathrm{CI})\end{array}$ & $\begin{array}{c}\mathrm{RR} \\
(95 \% \mathrm{CI})\end{array}$ & $\begin{array}{c}\mathrm{EF} \\
(\%)\end{array}$ & $\begin{array}{c}\text { The degree of association } \\
\text { between the health } \\
\text { disorders and the work }\end{array}$ \\
\hline $\begin{array}{c}\text { Increased content of leptin } \\
\text { in the blood }\end{array}$ & $\begin{array}{c}1.89 \\
(1.03-3.9)\end{array}$ & $\begin{array}{c}1.49 \\
(0.95-2.35)\end{array}$ & 33.02 & Moderate \\
\hline $\begin{array}{c}\text { Increase content of uric acid } \\
\text { in the blood }\end{array}$ & $\begin{array}{c}5.48 \\
(2.87-10.50)\end{array}$ & $\begin{array}{c}2.10 \\
(1.58-2.78)\end{array}$ & 52.33 & High \\
\hline Metabolic syndrome & $\begin{array}{c}2 ., 04 \\
(1.1-4.23)\end{array}$ & $\begin{array}{c}1.58 \\
(1.02-2.52)\end{array}$ & 36.75 & Moderate \\
\hline
\end{tabular}

Thus, these findings support the occupational causality for development of the metabolic syndrome, which is a predictor of cardiovascular disease (hypertension, ischemic heart disease, cerebrovascular disease), and indicate aromatic hydrocarbons as an occupational factor of cardiovascular risk.

\section{References}

1. Gimranova G.G. Zabolevanija serdechno-sosudistoj sistemy u rabochih osnovnyh professij neftedobyvajushhej promyshlennosti [Cardiovascular diseases in workers of major occupations in the oil industry]. Bjulleten' VSNC SO RAMN, 2009, no. 1, pp. 68-72.

2. Izmerov N.F., Skvirskaja G.P. Uslovija truda kak faktor riska razvitija zabolevanij i smertnosti ot serdechno-sosudistoj patologii [Working conditions as a risk factor for developing diseases and death due to cardiovascular pathologies]. Bjulleten' VSNC SO RAMN, 2005, no. 2, pp. 14-20.

3. Izmerov N.F. Professional'nyj risk dlja zdorov'ja rabotnikov: rukovodstvo [Occupational health risk for workers: guidelines]. Ed. N.F. Izmerov, Je. I. Denisov. Moscow: Trovant, 2003. $448 \mathrm{p}$.

4. Korzhubaev A.G., Jeder L.V. Neftedobyvajushhaja promyshlennost' Rossii [Russian oil-extracting industry]. Burenie i neft', 2011, no. 4, pp. 3-8.

5. Konchalovskaja N.M. Serdechno-sosudistaja sistema pri dejstvii professional'nyh faktorov [The cardiovascular system under exposure to occupational factors]. Moscow: Medicina, 1976. 254 p.

6. Mosin L.M., Astahova Z.T. Vlijanie «tehnogennyh» himicheskih faktorov na osnovnye pokazateli funkcii serdca [The impact of «technogenic» chemical factors on the main heart function indicators]. Kardiologija, 1995, no. 11, p. 54.

7. Onishhenko G.G., Zajceva N.V., Zemljanova M.A. Gigienicheskaja indikacija posledstvij dlja zdorov'ja pri vneshnesredovoj jekspozicii himicheskih faktorov [Environmental health indication of the potential for health problems following environmental exposure to chemical factors]. Ed. G.G. Onishhenko. Perm': Knizhnyj format,

$2011.532 \mathrm{p}$.

8. Rossijskaja jenciklopedija po medicine truda [Russian encyclopedia on occupational medicine]. Ed. N.F. Izmerov. Moscow: Medicina, 2005. 653 p.

9. UrazaevaJe.R. Sostojanie serdechno-sosudistoj sistemy u rabochih 
neftedobyvajushhej promyshlennosti [The condition of the cardiovascular system in oilextracting industry workers]. Problemy gigienicheskoj bezopasnosti i upravlenijafaktorami riska dlja zdorov'ja naselenija: mater nauch.-praktkonf, N. Novgorod, 2004, pp. 301-303.

10. Kotseva K., Popov T. Study of the cardiovascular effects of occupational exposure to organic solvents.

Int. Arch. Occup. Environ. Health, 1998, vol. 71, pp. 87-91.

11. Kristensen T.S. Cardiovascular diseases and the work environment. A critical review of the epidemiologic literature on chemical factors. Scand. J. WorkEnviron. Health, 1989, vol. 15, pp. 245-264. 